\title{
STAMPING OUT ISIS: METAPHORICAL EXPRESSIONS ABOUT TERRORISM IN DONALD TRUMP'S CAMPAIGN SPEECHES
}

\author{
UDC 81'373.612.2:324
}

\author{
Ivan Stamenković \\ University of Niš, Faculty of Philosophy, Niš, Serbia
}

\begin{abstract}
The 2016 US Presidential Elections brought about one of the fiercest election campaigns so far, ending in a tight victory of Donald Trump, the Republican candidate, over Hillary Clinton, the candidate of the Democrats. The public appearances Trump made at rallies were one of the main tools he used in profiling himself as the new leader of America. In the light of the unstable situation in the world and the frequent terrorist attacks on Western states, Trump's rhetoric regarding the issue of "Radical Islamic terrorism" was the key factor that propelled him towards victory (Azarian 2016). When he tackled the problem of terrorism, one of the discourse mechanisms that he used in abundance was a set of conceptual metaphors drawn from different spheres of human experience. The aim of this research will be to contribute to the role metaphor plays in discourse by highlighting some of the most salient and frequent metaphors in Trump's terrorism rhetoric, including the conceptualizations involved and their conceptual implications in discourse.
\end{abstract}

Key words: conceptual metaphor, terrorism, Donald Trump, ISIS

\section{INTRODUCTION}

The 2016 US Presidential Elections brought about one of the fiercest election campaigns so far, ending in a tight victory of Donald Trump, the Republican candidate, over Hillary Clinton, the candidate of the Democrats. Trump, a successful businessman, was seen as an inexperienced politician who would not be able to find his way in the election race; however, his sharp and characteristic rhetoric and radical new ideas first pushed him towards winning the front-runner status in the Republican primaries, and ultimately made him the $45^{\text {th }}$ president of the United States. The public appearances Trump made at rallies were one of the main tools he used in profiling himself as the new leader of America. Taking into consideration that everything the candidates say during a campaign is filtered through a "linguistic lens" and contributes to the voters' creation of

Submitted May $4^{\text {th }} 2017$, accepted for publication December $16^{\text {th }}, 2017$

Corresponding author: Ivan Stamenković

Faculty of Philosophy, Ćirila i Metodija 2, 18000 Niš, Serbia

E-mail: ivan.stamenkovic.1987@gmail.com 
the candidates' “presidential selves" (Sclafani 2016), Trump's unconventional speaking techniques sparked a lot of interest among political and linguistic analysts.

Terrorism was one of the main problems Donald Trump addressed in his speeches. Certain analysts go as far as to claim that, in the light of the unstable situation in the world and the frequent terrorist attacks on Western states, Trump's rhetoric regarding the issue of "Radical Islamic terrorism" was the key factor that propelled him towards victory (Azarian 2016). When he tackled the problem of terrorism, one of the discourse mechanisms that he used in abundance was a set of conceptual metaphors drawn from different spheres of human experience. The metaphor is a very widespread rhetorical tool that politicians use both to enable citizens to understand complex issues and shape their political opinions (Lakoff 2008; Cammaerts 2012). The focus of this paper is Donald Trump's use of conceptual metaphor in talking about terrorism in his campaign speeches. The aim of this research will be to contribute to the role metaphor plays in discourse by highlighting some of the most salient and frequent metaphors in Trump's terrorism rhetoric, including the conceptualizations involved and their conceptual implications in discourse.

First, the theoretical framework of the Conceptual Metaphor Theory will be presented, followed by a brief overview of the previous relevant research in this area. The next section contains a brief overview of the relevant geopolitical situation in the world, followed by a detailed explanation of the corpus and methodology that was used for the analysis, and the presentation and discussion of the results. The paper will close with a brief recapitulation of the research aims and the insights gained from the corpus analysis.

\section{THEORETICAL FRAMEWORK}

The traditional view of the metaphor limited this term to the embellished language which was used in poetry and rhetoric for a persuasive purpose. These traditional approaches to metaphors addressed the concept at the level of individual utterances, regarding it as a deviation or an anomaly in that the meaning of an utterance is something other than the logical literal truth of that utterance, i.e., its propositional meaning (Lakoff 1993: 1; Ma and Liu 2008: 260-261). However, Lakoff and Johnson's ground-breaking work Metaphors We Live By (1980) changed this conception by arguing that most of our ordinary conceptual system is metaphorical in nature and that metaphors were an integral, even a central part of language, instead of its peripheral element. This so-called cognitive approach gives the metaphor a key role not only in structuring our language, but also in structuring our thoughts and actions; therefore, the metaphor became a matter central to the way our mind functions, and not just an instance in language.

This new theory of the conceptual metaphor defined it as "understanding and experiencing one kind of thing in terms of another" (Lakoff and Johnson 1980: 50). Conceptual metaphors "consist of a source domain and a target domain, as well as a set of mappings between them" (Kövecses 2002: 15). A suitable formulaic expression for the firmly structured systematic mappings within a conceptual metaphor is CONCEPTUAL DOMAIN (A) IS CONCEPTUAL DOMAIN (B) (Kövecses 2002: 4). The source domain is more concrete and based on human experience, and it refers to the conceptual domain used to help understand another conceptual domain, while the target domain is abstract, vague, and generally more difficult to understand than the more concrete source domain. (Kövecses 2002: 12). Conceptual Metaphor Theory poses that metaphor functions via a set of conceptual mappings, "a systematic set of associations between aspects of the target (i.e., its features, properties, and relations) and analogous aspects of the source" (Landau and Keefer 2015: 5). 
This mapping enables people to use the information about the source as a framework for understanding corresponding aspects of the target. A difference was established between the metaphorical expression, which was the aforementioned surface realization of the metaphor in language, and the conceptual metaphor, a cognitive process whereby one conceptual domain is understood in terms of another.

Turning to their function in political communication, an often-heard opinion is that politicians' frequent use of metaphors is their attempt to "make politics less abstract and more tangible for citizens or to voters" (Cammaerts 2012: 5). However, this is by no means the only reason metaphors are used in political communication. They do not only serve a descriptive purpose by facilitating our understanding of reality. Lakoff and Johnson (1980) agree that metaphors are instruments that construct views, ideas, and perspectives, thus "creat[ing] social reality and guid[ing] social action" (Lakoff and Johnson 1980: 156). Using a particular metaphor has a precise political aim, which becomes clear when one takes into consideration how politicians consciously appeal to the emotions of their readers/listeners in order to promote their political belief and seek their acceptance from potential voters (Borčić 2010: 140). This "constitutivist" view suggests that they are essential in the creation of a political reality (Mio 1997: 121). The following section will present some of the most important research done on conceptual metaphors in political discourse, with special emphasis on the way terrorism was portrayed using this rhetorical device and certain previous comments on the rhetoric of Donald Trump.

\section{PREVIOUS RESEARCH}

Due to the salient position conceptual metaphors take in political discourse, they were the subject matter of many research projects.

Starting from papers with a more general area of interest, Mio's (1997) comprehensive overview of research on metaphors in politics includes both theoretical writings, nonexperimental research papers, and experimental research that analyse how people respond to manipulation via metaphorical language. Apart from allowing the public to grasp complex issues in political events, it also uses the unconscious latent symbolic representations in people's minds, with the media playing a central role in their distribution.

Charteris-Black (2006) investigates the conceptual metaphors right-wing politicians used to talk about the immigration issue during the campaign for the 2005 elections in the United Kingdom. The two main areas recognized are 'natural disaster' metaphors, mostly in relation to fluids, and 'container' metaphors, which conceptualize the country as a closed area suffering from pressure build-up due to the influx of immigrants. The two types of concepts are interconnected because the "bounded area" element introduces a space protected from outside factors. Along with the obvious spatial aspect, the container metaphor introduces a temporal element in the sense that preventing the breach of the container boundaries (border control) would slow down social change (a temporal issue) influenced by the influx of immigrants, which was especially convenient to political forces that opposed social change, i.e., the right-wing parties.

By using critical metaphor analysis (Charteris-Black 2004), Cammaerts (2012) explores the way North-Belgian politicians and journalists strategically used metaphors in the Belgian 2007-2011 constitutional crisis. This identified four overarching categories - sports and games metaphors, war metaphors, culinary metaphors, and transport metaphors. Some of the metaphors identified were consistently used throughout the long period examined, and they were all designed to influence the political negotiations through embedded ideological 
intentions. The nationalistic politicians proved to be especially creative in producing political metaphors, thus shaping public discourse and the political "reality" by promoting a divisive world view and "clear boundaries between us and them, between the interests of the Self and those of the Other" (Cammaerts 2012: 18).

More specifically, several research papers emphasized the significance of metaphorical conceptualizations in framing (and justifying) terrorism and conflict.

On several occasions, George Lakoff commented on the role of political rhetoric in getting popular support for US interventions in the last decade of the $20^{\text {th }}$ and the first decade of the $21^{\text {st }}$ century. Lakoff (1991) investigates the conceptual system George H. W. Bush used to justify the United States intervention in the first Gulf War. Lakoff (1991: 4) identifies a "fairy tale structure", which demands a victim, a villain, and a hero, epitomized in Kuwait, Iraq (and Saddam Hussein, its president at that time) and the US respectively. This structure set the scene for a rescue scenario, which gives moral justification to the war and a way for American citizens to accept it.

Lakoff (2001) investigated how George W. Bush's administration framed the attack on the World Trade Center on September 11, 2001, by using conceptual images. He argues that images can be seen as symbols reflecting our identity. On the one hand, the World Trade Center buildings denoted the society, a person standing upright, so the collapse of the towers stood for the people being killed. On the other hand, the Pentagon represented a vaginal symbol, and the plane penetrated it as a missile, evoking images of rape. This symbolism directly contributed to the justification of the second US intervention in Iraq in 2003.

Lakoff (2005) summarizes the way the frame for fighting terrorism shifted from "war on terror" to "global struggle against violent extremism." He argues that the war conceptual frame was useful because it rallied the patriotic efforts of the USA and implied a clear endyou win the war and terrorism is defeated. However, after a series of terrorist attacks in Europe in the first decade of the $21^{\text {st }}$ century, it became clear that this was not a feasible frame. The second phrase and its vagueness implied there is no foreseeable end to the conflict, justifying interventions on a global scale against any factor that could be dubbed "extreme."

Hülsse and Spencer (2008) suggest a shift of perspective in studying terrorism from an actor-centred to a discourse-centred perspective since the terrorist actor is a product of discourse. To clarify, the discourse of the terrorists' opponents establishes the motivations, strategies, and goals of terrorists. The article argues for a discourse approach that highlights the role of metaphors in constituting reality and analyses the way German popular press constructed Al-Qaeda using metaphors. The results suggest that terrorism was first conceptualized as war, but that the main metaphor shifted towards crime around 2004. AlQaeda was constituted as a criminal, which marked a shift from an external to an internal threat, changing anti-terrorist practices towards a judicial rather than a military response.

García (2009) investigates the metaphorical conceptualization of terrorism in political speeches by José Luis Rodriguez Zapatero, the Prime Minister of Spain at that time. The research has shown that the conceptual framework of fight dominates discourse on terrorism, which performs different functions at the cognitive, rhetorical, and ideological level to further his anti-terrorism political ideology. Similarly, García (2010) once again investigated the discursive construction of terrorism in Zapatero's speeches, but this time by analysing the medical metaphors in the political speeches and their persuasive role. The author investigated three overarching metaphorical mappings: TERRORISM IS A DISEASE, THE GOVERNMENT IS THE DOCTOR, and THE SOCIETY IS THE PATIENT.

Charteris-Black (2011) analyses the systematic use of metaphors and their interaction with other rhetorical tools in creating a political myth, an effective persuasion technique. By 
applying critical metaphor analysis to the corpus consisting of speeches of major British and American leaders, he illustrates the central role metaphor and political myth play in persuasion. Having analysed the characteristic rhetorical style of each leader, he reveals how their intentional 'spin' is skilfully implemented. The politicians examined in Charteris-Black (2011) also addressed terrorism. For example, Margaret Thatcher designated terrorism as a social problem and called for a fight against it. Before September 11, 2001, Tony Blair referred to criminal and anti-social behaviour as evil, a characterization that he started using for terrorism after the attacks. George W. Bush often used personification for evaluative purposes, giving terrorism and terrorists negative labels such as vermin, insects, and parasites. Apart from that, he conceptualized them as dangerous animals and frequently evoked hunting metaphors, additionally depersonalizing the enemy in order to justify their destruction.

Finally, there are certain articles that specifically analyse the rhetoric of Donald Trump in the 2016 presidential campaign from a perspective of the conceptual metaphors and images he used.

Lakoff (2016a, 2016b) gives a detailed analysis of Donald Trump's rhetoric through a wider sociolinguistic and cultural perspective, appealing to the Strict Father worldview he says conservatives allegedly share. Combining that with simple expressions of direct causation (as opposed to more complex systemic causation), Trump appealed to the masses of American biconceptuals, people with moderate ideologies who have both the progressive and the conservative political moral worldviews (Lakoff 2016a). He finally argues that these two frames imply mutual inhibition and that the presence of language discussing a certain worldview strengthens it, be it Trump himself producing the language or the media commenting on his actions. His conclusion is that Trump's characteristic use of language and rhetorical devices is one of the reasons for such widespread popular support.

\section{HistORICAL AND GEOPOLITICAL CONTEXT}

Before the description of the research, this section will provide a short overview of the geopolitical context necessary for understanding certain issues discussed later. The Arab Spring, a series of democratic uprisings that spread across the Arab World, thoroughly destabilized the Middle East and Northern Africa. In Syria, protests against the regime of Bashar al-Assad grew into a full-scale civil war between the government forces and the rebels, throwing large portions of the country into a state of anarchy. Coupled with the US forces moving out of Iraq in 2011, this created fertile ground for the development of different terrorist organizations. One of them, the Islamic State of Iraq and Syria (ISIS), quickly became the most prominent and the most well-organized terrorist organization. It had a large portion of territory under its control while its brutal fighting measures put it in the spotlight of the world community. A series of brutal terrorist attacks, culminating with the Paris terror attacks on November 13, 2015, solidified its position as the most dangerous threat to stability in the Middle East and the whole world. Their reach did not miss the USA, where the two most prominent attacks were the San Bernardino shooting in December 2015 and the Orlando nightclub shooting on June 12, 2016.

\section{Methodology}

The corpus for the analysis of metaphors Donald Trump used in his presidential campaign consists of 12 transcripts of his speeches given from June 16, 2015 (when he announced his 
candidacy) to September 12, 2016, 10 transcripts of speeches ranging from October 21 to November 9, 2016 (the speech after he won the elections), and the inaugural address he gave on January 20, 2017, totalling 80,211 words. The reason sampling was performed in such a way is the diversification of material in order to include speeches from the beginning and the end of the campaign. The assumption was that stretches of consecutive speeches would contain repetitions in the rhetorical devices used, thus limiting the variety of metaphors present. The speech transcripts were sampled from the website of The American Presidency Project (APP, http://www.presidency.ucsb.edu), a non-profit organization which collects transcripts of presidential documents.

The corpus material was analysed manually in order to detect the conceptual metaphors that were used to portray terrorism. The focus was placed on all metaphorical expressions used in terrorism rhetoric, regardless of the fact whether they were used to portray terrorism as a phenomenon, states that support it, or Radical Islam as the alleged ideological precursor to terrorism. The research relied on some of the tenets of the Metaphor Identification Procedure (Pragglejaz Group 2007) in order to reduce subjectivity in the identification of the metaphorical character of the expressions. This included identifying the contextual and basic meaning of every lexical item, followed by their comparison. If the conceptual and basic meaning of the expressions were different, only then was the expression deemed metaphorical in nature. Some aspects of Critical Metaphor Analysis (Charteris-Black 2004) were used to analyse the relevance of these metaphors in wider discourse since it approached the discovered metaphors at a descriptive, an interpretative, and a motivational level. An additional tool used in identifying the source and target domains of the metaphors was the Master Metaphor List (Lakoff, Espenson and Schwartz 1991).

After identifying the most prominent metaphors used in conceptualizing terrorism, the metaphorical expressions were divided into groups according to their source domain, but wider conceptual frameworks were also considered. The following section presents the categories of metaphors found and tries to explain their wider discursive implications.

\section{RESULTS AND DISCUSSION}

The source domains that Donald Trump used in conceptual metaphors related to terrorism in his campaign speeches are given in Figure 1, including the number of expressions for every source domain.

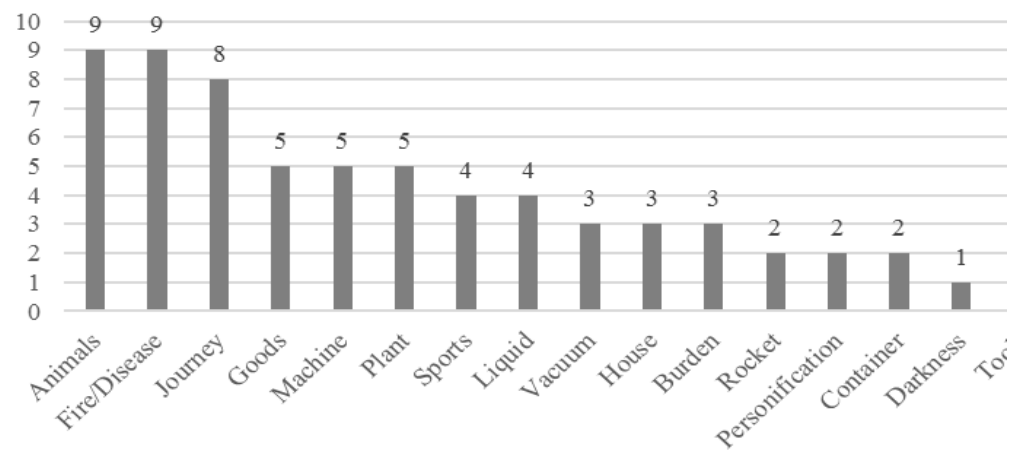

Fig. 1 The source domains used in conceptual metaphors in Donald Trump's speeches and the number of examples they are used in 
The metaphorical expressions mapped from these source domains are discussed in more detail in the remainder of this subsection.

\subsection{Animal metaphors}

Animal metaphors are often used for terrorists, especially in the mapping TERRORISTS ARE WILD ANIMALS (Pavlikova 2015: 44). This conceptualization increases the negative evaluation of the terrorists, because wild animals are commonly considered to act impulsively and violently, as opposed to human beings. In the current corpus, individual terrorists are not conceptualized as animals, but terrorism and ISIS, abstract concepts, are accorded the properties of wild animals.

(1) Islamic terrorism is eating up large portions of the Middle East. (June 16, 2015) ${ }^{1}$

(2) The Hillary Clinton foreign policy has cost America thousands of lives and trillions of dollars - and unleashed ISIS across the world. (June 22, 2016)

(3) My opponent unleashed ISIS on the world. (October 26, 2016)

Example (1) uses the metaphor TERRORISM IS A DANGEROUS ANIMAL, which is portrayed preying on the Middle East. Furthermore, examples (2) and (3) use the metaphor ISIS IS A DANGEROUS ANIMAL, which portrays an organization that was once under control (on a leash), now wreaking havoc across the region. These dehumanizing connotations accorded to terrorism and terrorist groups rhetorically justify all the necessary measures to combat them, i.e., hunting and killing the wild animals threatening peace. Since war, terrorism and killing are some of the major taboos in Western culture, Allan \& Burridge (2006: 235) note that

[a]cts of war are often cloaked in language that masks the true purpose and nature of acts of killing. By using deodorant language to describe dirty deeds, it is perhaps easier to commit those dirty deeds.

Therefore, euphemistic expressions are used to mitigate the unpleasant character of these taboo terms, with metaphors being one of the main vehicles in creating these euphemisms.

\subsection{Fire metaphors}

Trump uses the metaphor TERRORISM IS FIRE to highlight its destructive power. This justifies the fight against it, or, in the context of fire, putting out the fire:

(4) Instead, we must work with all of our allies who share our goal of destroying ISIS and stamping out Islamic terrorism and doing it now, doing it quickly. (July 21, 2016)

Moreover, another trait of fire is its ability to quickly spread and cause damage to the territory it spreads to:

(5) Arm in arm, we will rescue the nation from the Obama-Clinton disaster, which is exactly what it is, that has bled our country dry and spread terrorism unabated across the world, that's what's happening. (August 5, 2016)

(6) Containing the spread of radical Islam must be a major foreign policy goal of the United States. (April 27, 2016)

\footnotetext{
${ }^{1}$ The italics in all the examples were added by the author as a means to emphasize the focus metaphorical expression.
} 
It must be noted that this metaphor does not only fit into the FIRE source domain, but that it can also fit into the DISEASE domain. Like fire, disease spreads in an epidemic, causes death and destruction, and its spread needs to be halted. No matter what source domain is mapped onto terrorism, the negative connotation and the necessity for stopping its spread is communicated to the public, thus legitimizing any necessary radical measures against it.

\subsection{Journey metaphors}

Trump often uses the source domain of a journey to create metaphors that illustrate progress towards a certain goal:

(7) Thanks to Hillary Clinton, Iran is now the dominant Islamic power in the Middle East, and on the road to nuclear weapons. (June 22, 2016)

(8) Another humiliation came when president Obama drew a red line in Syria-and the whole world knew it meant absolutely nothing. (July 21, 2016)

(9) NATO will be setting up a new program in order to combat terrorism a true step in the right direction. (July 21, 2016)

The previous examples all use the mapping LONGTERM PURPOSEFUL ACTIVITY IS A JOURNEY (Lakoff, Espenson and Schwartz 1991: 36). In example (7), Iran's nuclear program is a journey, with the goal of creating a nuclear bomb-Iran is allegedly creating the bomb, which means they are somewhere on the path towards it. Conversely, if the goal of the terrorists is establishing their own state in the Middle East, Syria included, President Obama tried to stop their progress by drawing a line that they were not allowed to cross, blocking the path of their journey (example (8)). Finally, example (9) shows a mapping within the journey metaphor MEANS ARE PATHS, so a step along a right path means that this move is a good means towards reaching the desired goal.

\subsection{Goods metaphors}

In order to simplify the way Hillary Clinton is causing harm to the United States and facilitate a negative emotional reaction from the voters, Trump uses a mapping that can be summed up as ILLEGAL OR DANGEROUS ACTIVITIES ARE GOODS, instead of explaining the complex mechanisms of immigration and foreign policy. Extremism and terrorism are conceptualized as physical things being imported into the country.

(10) We must stop importing extremism through senseless immigration policies. (April 27, 2016)

Since import is an intentional activity, it makes Clinton seem as deliberately doing harm to her country. Furthermore, other dangerous activities are also personified as things that Clinton delivers to Americans and other people:

(11) Yet, for all the money spent, all Clinton delivered was death, destruction and terrorism (October 23, 2016).

This is another example how metaphors can not only be used to present complex things to the general public, but also to influence public opinion.

\subsection{Machine metaphors}

This is one of the several submetaphors of the COMPLEX ABSTRACT SYSTEMS ARE COMPLEX PHYSICAL OBJECTS metaphor, including submetaphors with the source 
domains HUMAN BODY, BUILDINGS, MACHINES or PLANTS (Kövecses 2005: 209). In Trump's speeches, such complex systems are the United States (example (12)) or Iran's organizations allegedly sponsoring terrorism (example (13)). In both examples, the complex systems are conceptualized as machine-like systems:

(12) I said before, if crooked Hillary Clinton becomes president, terrorism will destroy the inner workings of our country. (August 5, 2016)

(13) Secondly, we will totally dismantle Iran's global terror network, which is big and powerful, but not powerful like us. (March 21, 2016)

On the one hand, if terrorism tampers with the mechanism of the national machine, it can hinder its functioning and even disable it. This additionally informs the voters that terrorists are present within their own country, working secretly to do them harm, and acts as a warning of the imminent threat. On the other hand, dismantling Iran's machinery that supports these terrorists is necessary for hindering the terrorists' efforts. Example (13) juxtaposes the American machine with Iran's, reassuring the people that it is more powerful. ${ }^{2}$

\subsection{Plant metaphors}

The characteristics of such a complex terrorist organization as ISIS is simplified for the general public through its comparison to a plant. This metaphor emerges from the conceptual mapping SOCIAL ORGANIZATIONS ARE PLANTS (Kövecses 2002: 8) the founding of the organization is planting its seeds (example (14)), its development is the growing of the plant (example (15)), and anyone helping the development of the organization is nurturing the growth of the plant (examples (16) and (17)):

(14) Iran has seeded terror groups all over the world. (March 21, 2016)

(15) Each of these actions have helped to throw the region into chaos, and gave ISIS the space it needs to grow and prosper. (April 27, 2016)

(16) The media talks about "homegrown," terrorism, but Islamic radicalism, and the networks that nurture it, are imports from overseas. (June 13, 2016)

(17) ISIS isn't even mentioned. It's not even mentioned during the Democratic Convention. And everyone's talking about it. The reason they can't mention it is because they grew it. (July 27, 2016)

In this case, the plant has a negative connotation and its growth and development is harmful, so it can be equated with a weed, destroying the healthy plants around it (Pavlikova 2015: 42).

\subsection{Sports metaphors}

Sports has always been a very productive metaphor for many domains, including politics, war, and any kind of competition in general (Cudd 2007: 52). In this case, the war against ISIS is seen as a sports match - a boxing match to be precise. The following examples show how the WAR IS SPORT mapping was concretized into the FIGHT AGAINST TERRORISM IS BOXING metaphor.

\footnotetext{
${ }^{2}$ Even though example (5) clearly refers to the term network, the verb dismantle points to the fact that this expression is not used metaphorically — at least not in a productive manner — but as a stock phrase, a cliché habitually used by a person or group, and that Trump was conceptualizing the terrorist network as a more complex structure. If network were used in a metaphorical manner, he would have probably used the term untangle.
} 
(18) Tonight, this candidate and the whole nation stand in their corner to support them, to send them our love, and to pledge in their honour that we will save countless more families from suffering and the same awful fate. (July 21, 2016)

(19) I would treat Vladimir Putin firmly but there's nothing that I can think of that I'd rather do than have Russia friendly as opposed to the way they are right now so that we can go and knock out ISIS together with other people and with other countries. (July 27, 2016)

(20) We get along with Russia, we go out together with others and we knock the hell out of ISIS, wouldn't that be great? (August 5, 2016)

In this imaginary boxing match, the states involved are the fighters, while the states aiding them are personalized as the coaches and people helping the boxers in their corners (example (18)). Just as a knock-out ends a boxing match, "knocking out" ISIS (examples (19) and (20)) stands for their ultimate defeat.

\subsection{Liquid metaphors}

Trump emphasizes immigration as the main way terrorists come to the country, which he often conceptualized through the usage of metaphors of liquid. This again has to do with the NATION IS A CONTAINER frame (Charteris-Black 2006), where the inside container is portrayed as more secure than its outside. By conceptualizing immigration as an influx of liquid (Chilton 2004: 117), the idea of security is endangered-now the container is no longer a safe haven, but is somehow "polluted" by the flow of outsiders, also indicating the perforation of the container (Charteris-Black 2006: 575).

(21) Clinton wants to allow Radical Islamic terrorists to pour into our country - they enslave women, and murder gays. (June 13, 2016)

The abstract concepts of violence and terrorism are also metaphorically conceptualized as liquid; however, the container metaphor is slightly modified - it is no longer a completely enclosed space, but a dam or wall encompassing the entire country:

(22) Of all my travels in this country, nothing has affected me more deeply than the time I have spent with the mothers and fathers who have lost their children to violence spilling across our border, which we can solve. (July 21, 2016)

Therefore, it is not the rupture that threatens the security of the container, but the fluid overflowing the barriers. This shifts the connotation from the strength of the stream of migration to the amount of fluid. By using this metaphor, Trump reaffirms that the number of migrants coming to the United States is already high enough and that the announced increase in their number will cause a flood inside the formerly safe area encircled by the dam. The limitations in space also suggest that, if the spilling continues, all those inside might be drowned in the stream of violence and terrorism. This is partially related to what CharterisBlack (2006: 570) calls "natural disaster metaphors".

\subsection{Vacuum metaphors}

One of the most popular metaphors regarding foreign policy of the United States in the Middle East is the "vacuum" metaphor (Pillar 2015). This concept has become an argument against the policy of Obama's administration invoked by those believing that the United States need to increase the intensity of their military interventions in the Middle East. Donald 
Trump also used this metaphor to discredit the policy of the Democrats and his opponent, Hillary Clinton.

(23) The vacuum was created that ISIS would fill. Iran, too, would rush in and fill the void, much to their unjust enrichment. (April 27, 2016)

(24) ISIS - was caused by them. They left a big vacuum. (November 7, 2016)

(25) The decision to overthrow the regime in Libya, then pushing for the overthrow of the regime in Syria, among other things, without plans for the day after, have created space for ISIS to expand and grow. (June 13, 2016)

This metaphor assumes the mapping ABSENCE OF GOVERNMENT IS ABSENCE OF SUBSTANCE, equating the alleged state of lawlessness with an empty space, ready to be filled by somebody else. This metaphor dismisses the local people, governments or armies and presupposes that a major military power must be present to fill this empty space and restore balance. It assumes that the important properties of the region are not really important if they do not include the intervention of an external power, in this case, the United States. This rhetorical device implies that filling a space, both through military force and other means, is a means of promoting U.S. interests (Pillar 2015). In this case, the absence of any foreign intervention led to the creation of a major terrorist power, ISIS.

\subsection{House metaphors}

One of the main measures Donald Trump proposed for stopping terrorism was controlling immigration and the influx of refugees from Muslim countries since he considered this a way for extremists to enter the United States and plan future terror attacks. Since the concept of states and their borders is difficult to imagine (Chilton and Ilyin 1993: 9), politicians have always resorted to metaphors so as to facilitate the understanding of this concept. The most effective means was the container metaphor, with the borders being the boundaries of the container that provide security for those within it (Charteris-Black 2006: 575). Once the container metaphor has been established, it is easy to extend it to other enclosed spaces, including the concept of STATE TERRITORY IS A HOUSE. This ties in with the STATE IS A PERSON mapping, entailing that as a person lives in a house, so does the state occupy a limited and invulnerable bordered space keeping it safe (Lakoff 1991: 3). Therefore, indiscriminate acceptance of immigrants could be seen as opening the door to the house for them without any control, which is illustrated in the following examples.

(26) Hillary Clinton, who already has the blood of so many on her hands, is now announcing that she is willing to put each and every one of our lives in harms' wayan open-door policy to criminals and terrorists to enter our country. (June 22, 2016)

(27) We're letting in Radical Islamic Terrorists right through the front door, and stamping their visas "approved" on the way in. (October 23, 2016)

(28) They've dragged us into foreign wars that have made us less safe, they have left our borders wide open at home, and they've shipped our jobs and wealth to other countries. (October 29, 2016)

This strategy is a good way to present the alleged danger of terrorism to the American public - just like people do not let strangers into their own home, they should apply the same judgment when accepting immigrants to their country. 


\subsection{Burden metaphors}

These metaphors are a derivation of the JOURNEY metaphor (Lakoff, Espenson and Schwartz 1991: 36), where purposeful activity is equated with a journey that has a start, an end, a path to connect them, and presents the progress as motion along that path. However, that motion is disabled or hindered if a burden is placed on the persons. Therefore, it must be lifted in order for the process to continue unimpeded.

(29) The ban will be lifted when we will [sic!] develop a responsible immigration policy that serves the interests and values of America. (June 13, 2016)

Furthermore, if the daily activities of citizens can be conceptualized as purposeful activities, then legislation that makes their life difficult can be seen as pressure being put on them, hindering their movement:

(30) This shooter in Orlando was the child of an immigrant father who supported one of the most repressive regimes on Earth. (June 13, 2016)

Therefore, these metaphors can be subsumed under the mapping DIFFICULTIES ARE IMPEDIMENTS TO MOTION.

\subsection{Rocket metaphors}

In this very unconventional use of metaphor, Donald Trump conceptualizes the rise of ISIS as a launching of a rocket. Since it is quite complicated for the voters to comprehend how a quasi-state organization like ISIS came to be, it is easier to use the metaphor that would map the success of ISIS, and terrorism in general, to a rocket lifting off the ground. Just like any undertaking, the launch of the rocket from the ground requires a large amount of initial energy which propels it upward. A metaphor which visually ties in with this image is the spatial mappings SUCCESS IS UPWARD MOTION and INCREASE IN QUANTITY IS UPWARD MOTION (Lakoff 2016c: 138)_-since ISIS is being launched into the air, this motion indicates their successful military operations and the expansion of their territory. Furthermore, all the equipment/prerequisites for launching a rocket are seen as providing help to the rise of ISIS, and, according to Trump, the person responsible is his competitor, Hillary Clinton:

(31) Hillary Clinton's support for violent regime change in Syria has thrown the country into one of the bloodiest civil wars anyone has ever seen-while giving ISIS a launching pad for terrorism against the West. (June 22, 2016)

(32) Hillary Clinton's foreign policy helped launch ISIS. (July 16, 2016)

The resulting mappings ISIS IS A ROCKET and TERRORISM IS A ROCKET also point to the destructive character of this terror organization if it is considered that explosive missiles are often similar to rockets. Therefore, the US public is additionally reminded that they can be the target of terror attacks even though the distance between them and the afflicted region is significant.

\subsection{Other metaphors}

This section will cover some of the less frequent metaphorical expressions, which, nevertheless, play an important role in the election rhetoric of Donald Trump. Firstly, when evoking the morality of the terrorists' deeds, he uses the mapping BADNESS IS DARKNESS (Lakoff, Espenson and Schwartz 1991: 190), presented in example (33): 
(33) This is a very dark moment in America's history. (June 13, 2016)

The same topic is addressed in example (34) by using personification with the metaphor NATION IS A PERSON to rouse feelings of patriotism and stress the danger USA is in:

(34) It is a strike at the heart and soul of who we are as a nation. (June 13, 2016)

Furthermore, when another state is personified as a person, the American public is reassured through the image of the alleged sponsor of terrorism being choked:

(35) Iran was being choked by sanctions. (June 22, 2016)

The nation can also be metaphorically represented as a thing with order to facilitate explaining the complex political situation in Syria that caused the civil war. In example (36), the mappings used are COUNTRY IS A THING, and as a thing it can be placed in the state of war as a container, an extension of the STATE IS A CONTAINER mapping:

(36) Hillary Clinton's support for violent regime change in Syria has thrown the country into one of the bloodiest civil wars anyone has ever seen [...] (June 22, 2016)

Finally, to battle terrorism, the institutions need tools in the sense of both physical equipment and the logistic and legal framework that is required. In this sense, this is an example of the mapping MEANS ARE TOOLS:

(37) As President I will give our intelligence community, law enforcement and military the tools they need to prevent terrorist attacks. (June 13, 2016)

After the overview of all mappings that were, the following section will recapitulate the aims of the paper and summarize the results of the research.

\section{CONCLUSION}

This paper attempted to demonstrate the importance of metaphorical language in political rhetoric on the example of Donald Trump's speeches from the 2016 presidential elections campaign and his inaugural speech. More specifically, it examined how conceptual metaphors were systematically used in discourse related to the topic of terrorism in an attempt to demonstrate the central role metaphors play in political discourse and human thought.

Previous research indicated that politicians use conceptual metaphors not only to shed light on abstract and complicated notions by relating them to concepts familiar from everyday experience, but that they also strategically position them in their speeches in order to form the voters' opinion on a subject and justify certain decisions they might make. Even though the limited scope of this paper enabled it to point out only some of the metaphorical mappings in the domain of terrorism, it still reconfirmed the dual role of metaphors. Each of the sixteen source domains that were identified (animals, fire/disease, journey, goods, machine, plant, sports, liquid, vacuum, house, burden, rocket, person, container, darkness, and tools) primarily served the purpose of clarifying complex concepts of the way terrorism functions to the public; however, it also quite clearly emphasized the necessity of its destruction and the justifiability of intervening against it. Furthermore, metaphors serve the purpose of euphemisms used to mask the harsh taboo expressions related to war, terrorism, and killing.

A possible topic for further research could be the metaphorical expressions Trump used in other areas, like economy or foreign policy, while it would also be interesting to compare Trump's rhetorical devices with those of his predecessors. This would provide a 
complete image of the discourse that persuaded the voters to elect Donald Trump President of the United States. The attack of September 11, 2001, plunged the United States into perpetual fear of terrorist attacks and politicians have used this imagery to justify several foreign military interventions. Donald Trump gladly continued this tradition, skilfully using metaphors to dehumanize the terrorists and point out the imminent danger that terrorism poses to every American. Trump presented himself as a powerful leader ready to identify and tackle the problems his predecessor and competitor were not willing to handle. However, when politicians in power used this kind of rhetoric, especially in the second half of the $20^{\text {th }}$ and the beginning of the $21^{\text {st }}$ century, it often lead to the death of many innocent civilians, who fell victim to military actions justified by these expressions. Therefore, highlighting the mechanisms through which these rhetorical devices work might make the public aware of such manipulative properties and prevent the far-reaching consequences they can potentially have.

\section{REFERENCES}

Allan, K. and Burridge, K. (2006), Forbidden words: Taboo and the censoring of language. Cambridge: Cambridge University Press.

Azarian, B., (2016), Research Suggests Anxiety over Terrorism Helped Trump Win. https://www.psychologytoday. $\mathrm{com} / \mathrm{blog} /$ mindinthemachine/201612/researchsuggestsanxietyoverterrorismhelpedtrumpwin (March 3, 2017)

Borčić, N., (2010), "Konceptualne metafore u političkim intervjuima" [Conceptual Metaphors in Political Interviews], Medijske studije 1(1): pp. 136-155.

Cammaerts, B, (2012), "The Strategic Use of Metaphors by Political and Media Elites: the 2007-11 Belgian Constitutional Crisis", International journal of media \& cultural politics 8 (2/3): pp. 229-249.

Charteris-Black, J., (2004), Corpus Approaches to Critical Metaphor Analysis, Basingstoke: Palgrave MacMillan.

Charteris-Black, J., (2006), "Britain as a Container: Immigration Metaphors in the 2005 Election Campaign", Discourse \& Society 17(5): pp. 563-581.

Charteris-Black, J., (2011), Politics and Rhetoric: The Persuasive Power of Metaphor. $2^{\text {nd }}$ edition, New York: Palgrave Macmillan.

Chilton, P. and Ilyin M., (1993), "Metaphor in Political discourse: The Case of the Common European House", Discourse \& Society 4(1). 7-31.

Chilton, P., (2004), Analysing Political Discourse, London and New York: Routledge.

Cudd, A. E., (2007), "Sporting Metaphors: Competition and the Ethos of Capitalism", Journal of the Philosophy of Sport 34(1): pp. 52-67.

García, M. J. H., (2009), "Fight Metaphors in Spain's Presidential Speeches: JL Rodríguez Zapatero (20042007)", Revista Alieantina de Estudios Ingleses 22: pp. 127-153.

Garcia, M. J. H., (2010), "Diagnosing Terrorism in Spain: Medical Metaphors in Presidential Discourse", Southwest Journal of Linguistics 29(1): pp. 53-74.

Hülsse, R. and Spencer, A., (2008), "The Metaphor of Terror: Terrorism Studies and the Constructivist Turn", Security Dialogue 39(6): pp. 571-592.

Kövecses, Z., (2002), Metaphor. A Practical Introduction, Oxford: Oxford University Press.

Kövecses, Z., (2005), Metaphor in Culture: Universality and Variation, Cambridge: Cambridge University Press.

Lakoff, G. and Johnson, M., (1980), Metaphors We Live By. Chicago: Chicago University Press.

Lakoff, G., (1991), "Metaphor and War: the Metaphor System Used to Justify War in the Gulf", Peace Research 23(2/3): pp. 25-32.

Lakoff, G., Espenson J. and Schwartz, A., (1991), The Master Metaphor List, Technical report, University of California at Berkeley.

Lakoff, G., (1993), “The Contemporary Theory of Metaphor”, In: Ortony A. (ed.) Metaphor and Thought, $2^{\text {nd }}$ edition, Cambridge: Cambridge University Press: pp. 202-251.

Lakoff, G., (2001), "Metaphors of terror", In These Times: pp. 21-24.

Lakoff, G., (2005), War on Terror, Rest in Peace. http://www.alternet.org/story/23810/war_on_terror\% 2C_rest_in_peace (March 3, 2017)

Lakoff, G., (2008), The Political Mind: Why You Can't Understand 21st Century American Politics with an 18th Century Brain, New York: Viking.

Lakoff, G., (2016a), Why Trump? https://georgelakoff.com/2016/03/02/whytrump/ (February 16, 2017) 
Lakoff, G., (2016b), Understanding Trump's Use of Language. http://www.huffingtonpost.com/georgelakoff/understanding-trumps-use- b 11675280.html (February 16, 2017)

Lakoff, G., (2016c), "Mapping the Brain's Metaphor Circuitry: Metaphorical Thought in Everyday Reason,” In: Coulson, S. and Lai, V. T. (eds.) The Metaphorical Brain, Lausanne: Frontiers Media.

Landau, M. J. and Keefer, L. A., (2015), "The Persuasive Power of Political Metaphors", In: Forgas, J. P., Cooper, J. and Crano, W. D. (eds.) Social Psychology and Politics, New York: Psychology Press.

Ma, L. and Liu, A., (2008), “A Universal Approach to Metaphors”, Intercultural Communication Studies 7(1): pp. 260-268

Mio, J. S., (1997), "Metaphor and politics", Metaphor and symbol 12(2): pp. 113-133.

Pavlíková, K., (2015), (Counter)terrorism Metaphors in the Speeches of Barack Obama. Unpublished master's thesis, Masaryk University, Brno, Czech Republic.

Peters, G. and Woolley, J. T., "Donald J. Trump's 2016 Presidential Election Speeches and Remarks", The American Presidency Project. http://www.presidency.ucsb.edu/2016_election_speeches.php?candidate= $45 \&$ campaign $=2016$ TRUMP $\&$ doctype $=5000$

Pillar, R. R., (2015), Syria and the 'Vacuum' Metaphor. https://consortiumnews.com/2015/10/15/ syriaandthevacuummetaphor/ (March 9, 2016)

Pragglejazz Group, (2007), "MIP: a Method for Identifying Metaphorically Used Words in Discourse", Metaphor and Symbol 22: pp. 1-39.

Sclafani, J., (2016), The Idiolect of Donald Trump. https://blogs.scientificamerican.com/mindguestblog/ theidiolectofdonaldtrump/ (February 14, 2016)

\section{GAŠENJE IDIL-a: METAFORIČKI IZRAZI O TERORIZMU U GOVORIMA DONALNDA TRAMPA TOKOM KAMPANJE}

Predsedničke izbore u SAD održane 2016. godine obeležila je jedna od najžešćih predizbornih kampanja do sada, a završila se tesnom pobedom Donalda Trampa, republikanskog kandidata, nad Hilari Klinton, kandidatkinjom Demokrata. Govori Trampa na predizbornim mitinzima bili su jedno od glavnih sredstava koje je koristio da bi se profilisao kao novi vođa Amerike. Imajući u vidu nestabilnu situaciju u svetu i česte terorističke napade na zapadne države, Trampova retorika $u$ vezi sa pitanjem ,,radikalnog islamskog terorizma“ bila je ključni faktor koji ga je doveo do pobede (Azarian 2016). Kada se uhvatio u koštac sa problemom terorizma, jedan od diskursnih mehanizama koje je stalno koristio bio je skup konceptualnih metafora zasnovanih na različitim sferama ljudskog iskustva. Cilj ovog istraživanja je da doprinese istraživanju uloge koju metafore imaju u diskursu tako što će istaći najupadljivije i najčešće metafore u Trampovoj retorici o terorizmu, uključujući prateću konceptualizaciju i njihove konceptualne implikacije u diskursu.

Ključne reči: konceptualne metafore, terorizam, Donald Tramp, IDIL

\section{APPENDIX}

\section{The list of all metaphorical expressions found in the corpus}

\section{ANIMALS}

Islamic terrorism is eating up large portions of the Middle East. (June 16, 2015)

The Hillary Clinton foreign policy has cost America thousands of lives and trillions of dollars-and unleashed ISIS across the world. (June 22, 2016)

My opponent unleashed ISIS on the world. (October 26, 2016)

We tore up what institutions they had and then were surprised at what we unleashed. (April 27, 2016)

For instance, the last major NATO mission was Hillary Clinton's war in Libya. That mission helped unleash ISIS on a new continent. (June 13, 2016) 
She carried out her dangerous email scheme at the same time as her bad judgement and enthusiasm for regime change was unleashing ISIS across the world. (July 11, 2016)

To this day, she still won't take accountability for her role in unleashing ISIS across the Middle East — or for putting Iran on the path to a nuclear weapon. (September 12, 2016)

She unleashed ISIS and turmoil in Iraq, Syria and Libya. (October 23, 2016)

Hillary's policies unleashed ISIS, empowered Iran [...] (October 29, 2016)

\section{FIRE/DISEASE}

Instead, we must work with all of our allies who share our goal of destroying ISIS and stamping out Islamic terrorism and doing it now, doing it quickly. (July 21, 2016)

Arm in arm, we will rescue the nation from the Obama-Clinton disaster, which is exactly what it is, that has bled our country dry and spread terrorism unabated across the world, that's what's happening. (August 5, 2016)

Containing the spread of radical Islam must be a major foreign policy goal of the United States. (April 27, 2016)

We need a long-term plan to halt the spread and reach of radical Islam. (April 27, 2016)

ISIS has spread across the region, and the world. (July 21, 2016)

Hillary's plan includes an open border with the Middle East-meaning generations of radicalism and terrorism spreading and growing within our shores. (October 21, 2016)

[...] meaning generations of radicalism and terrorism spreading and growing within your communities and near your families. (October 23, 2016)

Hillary's immigration plans mean generations of terrorism, extremism and radicalism spreading into your schools and communities here in Michigan. (October 31, 2016)

Her decisions spread death, destruction and terrorism everywhere she touched. (June 22, 2016)

\section{JOURNEY}

But this has to be a two-way street - they must also be good to us and remember us and all we are doing for them. (April 27, 2016)

Another humiliation came when president Obama drew a red line in Syria - and the whole world knew it meant absolutely nothing. (July 21, 2016)

Thanks to Hillary Clinton, Iran is now the dominant Islamic power in the Middle East, and on the road to nuclear weapons. (June 22, 2016)

Iraq, Syria, all into chaos. And Iran is on a path to nuclear weapons. (July 16, 2016)

Egypt was turned over to the radical Muslim brotherhood, forcing the military to retake control. Iraq is in chaos. Iran is on the path to nuclear weapons. (July 21, 2016)

NATO will be setting up a new program in order to combat terrorism a true step in the right direction. (July 21, 2016)

[...]- or for putting Iran on the path to a nuclear weapon. (September 12, 20016)

We gave them a path to nuclear weapons. (November 7, 2016)

GOODS

We must stop importing extremism through senseless immigration policies. (April 27, 2016)

We are importing Radical Islamic Terrorism into the West through a failed immigration system (June 13, 2016)

Yet, for all the money spent, all Clinton delivered was death, destruction and terrorism (October 23, 2016).

Her plan will import generations of terrorism, extremism and radicalism into your schools and throughout your communities. (November 7, 2016) 
The same people who've wasted $\$ 6$ trillion on wars in the Middle East that have produced only more terrorism, more death, and more suffering (October 26, 2016)

\section{MACHINE}

I said before, if crooked Hillary Clinton becomes president, terrorism will destroy the inner workings of our country. (August 5, 2016)

Secondly, we will totally dismantle Iran's global terror network, which is big and powerful, but not powerful like us. (March 21, 2016)

The deal doesn't even require Iran to dismantle its military nuclear capability. (March 21, 2016)

Iran is the biggest sponsor of terrorism around the world and we will work to dismantle that reach, believe me, believe me. (March 21, 2016)

My number one priority is to dismantle the disastrous deal with Iran. (March 21, 2016)

\section{PLANT}

Iran has seeded terror groups all over the world. (March 21, 2016)

Each of these actions have helped to throw the region into chaos, and gave ISIS the space it needs to grow and prosper. (April 27, 2016)

The media talks about "homegrown," terrorism, but Islamic radicalism, and the networks that nurture it, are imports from overseas. (June 13, 2016)

ISIS isn't even mentioned. It's not even mentioned during the Democratic Convention. And everyone's talking about it. The reason they can't mention it is because they grew it. (July 27, 2016) The bottom line is that Hillary supports the policies that bring the threat of Radical Islam into America, and allow it to grow overseas. (June 13, 2016)

\section{SPORTS}

Tonight, this candidate and the whole nation stand in their corner to support them, to send them our love, and to pledge in their honor that we will save countless more families from suffering and the same awful fate. (July 21, 2016)

I would treat Vladimir Putin firmly but there's nothing that I can think of that I'd rather do than have Russia friendly as opposed to the way they are right now so that we can go and knock out ISIS together with other people and with other countries. (July 27, 2016)

We get along with Russia, we go out together with others and we knock the hell out of ISIS, wouldn't that be great? (August 5, 2016)

The bigger problem is that they can keep the terms and still get the bomb by simply running out the clock. (March 21, 2016)

\section{LIQUID}

Clinton wants to allow Radical Islamic terrorists to pour into our country-they enslave women, and murder gays. (June 13, 2016)

Of all my travels in this country, nothing has affected me more deeply than the time I have spent with the mothers and fathers who have lost their children to violence spilling across our border, which we can solve. (July 21, 2016)

We cannot continue to allow thousands upon thousands of people to pour into our country, many of whom have the same thought process as this savage killer. (June 13, 2016)

We have to stop the tremendous flow of Syrian refugees into the United States [...] (June 13, 2016)

\section{VACUUM}

The vacuum was created that ISIS would fill. Iran, too, would rush in and fill the void, much to their unjust enrichment. (April 27, 2016) 
ISIS - was caused by them. They left a big vacuum. (November 7, 2016)

The decision to overthrow the regime in Libya, then pushing for the overthrow of the regime in Syria, among other things, without plans for the day after, have created space for ISIS to expand and grow. (June 13, 2016)

\section{HOUSE}

Hillary Clinton, who already has the blood of so many on her hands, is now announcing that she is willing to put each and every one of our lives in harms' way-an open-door policy to criminals and terrorists to enter our country. (June 22, 2016)

We're letting in Radical Islamic Terrorists right through the front door, and stamping their visas "approved" on the way in. (October 23, 2016)

They've dragged us into foreign wars that have made us less safe, they have left our borders wide open at home, and they've shipped our jobs and wealth to other countries. (October 29, 2016)

\section{BURDEN}

The ban will be lifted when we will develop a responsible immigration policy that serves the interests and values of America (June 13, 2016).

The Sultan of Brunei has pushed oppressive Sharia law, including the punishment of death by stoning for being gay. (June 22, 2016)

This shooter in Orlando was the child of an immigrant father who supported one of the most repressive regimes on Earth. (June 13, 2016)

\section{ROCKET}

Hillary Clinton's support for violent regime change in Syria has thrown the country into one of the bloodiest civil wars anyone has ever seen-while giving ISIS a launching pad for terrorism against the West. (June 22, 2016)

Hillary Clinton's foreign policy helped launch ISIS. (July 16, 2016)

PERSON

It is a strike at the heart and soul of who we are as a nation. (June 13, 2016)

Iran was being choked by sanctions. (June 22, 2016)

\section{CONTAINER}

Hillary Clinton's support for violent regime change in Syria has thrown the country into one of the bloodiest civil wars anyone has ever seen [...] (June 22, 2016)

We have to control the amount of future immigration into this country to prevent large pockets of radicalization from forming inside America. (June 13, 2016)

\section{DARKNESS}

This is a very dark moment in America's history. (June 13, 2016)

\section{TOOLS}

As President I will give our intelligence community, law enforcement and military the tools they need to prevent terrorist attacks. (June 13, 2016) 